Comment le mal vient aux hommes

\title{
Comment le mal vient aux hommes : 1551-1645, la rumeur sur le mal
}

Catherine Lisak

\section{CpenEdition}

Journals

Édition électronique

URL : http://journals.openedition.org/shakespeare/1146

DOI : 10.4000/shakespeare.1146

ISSN : 2271-6424

Éditeur

Société Française Shakespeare

Édition imprimée

Date de publication : 1 novembre 1997

Pagination : 101-109

Référence électronique

Catherine Lisak, «Comment le mal vient aux hommes : 1551-1645, la rumeur sur le mal », Actes des congrès de la Société française Shakespeare [En ligne], 15 | 1997, mis en ligne le 01 janvier 2007,

consulté le 24 avril 2019. URL : http://journals.openedition.org/shakespeare/1146 ; DOI : 10.4000/ shakespeare.1146 


\section{COMMENT LE MAL VIENT A U X}

HOM MES :

\section{1-1645, LA RUMEUR SUR LE MAL}

I. «Comment le mal vient aux hommes» annonce une réflexion sur le mode de l'interrogation et de la démonstration, une explication à donner sur le mode de l'argumentation rationnelle comme sur celui d'un récit, au demeurant quelque peu énigmatique. Cet intitulé servira de fil conducteur dans une approche de cette question sur le mal qui ne laisse transparaître dans sa formulation ni origine ni fin. Cette interrogation conclut déjà implicitement sur une réalité substantielle et sur une antériorité axiomatique du mal. Dans cette question, l'ellipse de la principale fait des hommes les objets d'une interrogation, là où le mal s'affiche comme doublement sujet - à la fois point de mire de l'adverbe «comment» et principe moteur du verbe «vient». C'est bel et bien du mal qu'il est question et le mal qui est en question. Toutes les assurances semblent aussitôt se dérober devant l'insoluble du mal qui effraie et par l'importante part d'ombre et de non-sens qu'il suppose.

Question angoissante, en effet, que celle de savoir comment l'homme perd possession de sa propre essence, et devient littéralement un être possédé L'ambivalence du «comment» dit simultanément l'exigence de compréhension et le cri d'appréhension, l'interrogation et le scandale, la perplexité et la frayeur de celui qui, à tenter d'y voir plus clair, resterait interdit face à une explication nécessaire mais toujours impossible.

La question, peut-être historiquement première, et parmi les plus souvent posées, de l'avènement du mal chez l'homme, demeure sans perspective de réponse si ce n'est l'impasse, c'est-à-dire le constat d'un écart jamais comblé entre la problématique du mal et sa résolution. Cet écart est accentué par la 
fonction critique de la question ontologique qui exaspère les interrogations sans entrevoir de solutions.

Et pourtant, en dépit de ce questionnement qui ne trouve pas de réponse mais épaissit l'aspect énigmatique qui gouverne le problème du mal, l'énoncé laisserait pressentir une possibilité d'explication rationnelle - «comment» qui viendrait élucider, de part en part, le processus d'enclenchement qui lie intrinsèquement l'homme au mal. Il se proposerait de présenter sous la lumière de l'évidence les procédures et les moyens complexes qui déclenchent la transformation fondatrice de notre humanité, pour ainsi intégrer le mal à un ordre du monde et de l'homme, ou à un ordre tout court.

La formulation de l'intitulé suggère, par ailleurs, la résorption de tous les discours en un seul mot - «comment» - et la réorientation de ces discours jusqu'alors portés sur la seule question de l'origine du mal. Car la phrase ne met pas l'accent sur le complément de provenance et sur d'où vient le mal. Elle ne problématise pas non plus le point d'aboutissement qui est donné d'office - les hommes.

L'énoncé implique, en fait, un déplacement de la question classique du mal, une modification de perspective qui définirait le mal en termes de dynamisme. L'intitulé fait ainsi porter notre attention sur le mécanisme du mal dans son cheminement vers l'homme. Il propose de s'attarder sur son mode de conduite ou de circulation, ce qui supposerait le déploiement d'un itinéraire et donc une histoire - un récit, le «comment» étant propre à une pensée rétrospective.

De sorte que le seul récit à exclure à ce stade de notre étude est le premier récit de la Genèse, où rien ne suggère encore l'éventualité d'un tel phénomène.

Il s'agirait plutôt d'un récit qui, si on s'en réfère une fois encore à la formulation de l'énoncé, tient de l'énigme par les multiples interprétations paradoxales que cette phrase fait miroiter.

Car déjà en lui-même l'énoncé fait valoir la distance qui recule et rapproche conjointement l'homme du mal; il souligne l'effective connaissance du mal en même temps qu'il rappelle sa méconnaissance foncière. Il donne à penser le mal comme représentation de l'insondable mais, en fait, simultanément, comme ultime point de repère par rapport auquel l'homme est amené à se connaître. Il fait de l'homme l'objet du mal, et le mal apparaît alors comme l'indicateur de ses limitations et de sa finitude essentielle. Et pourtant, «comment le mal vient aux hommes» dit avant tout comment, dans sa manière d'agir, l'homme articule le principe de son aliénation et la réalisation de son identité.

Concluons, donc, à ce point de notre enquête, qu'il ne s'agit pas de savoir ce qu'est en lui-même le mal, mais de s'interroger sur la manière dont les hommes ont éprouvé le besoin pressant et permanent d'introduire, dans la chronologie fictive de leur existence, comme par un coup de théâtre, un 
concept qui leur échappe et dont la pesanteur les accable, mais à partir duquel ils ont pu commencer à mesurer leur valeur dans le monde naturel et humain en accédant, à travers cette notion opaque, à une conscience d'eux-mêmes.

II. Entre l'humanisme de la Renaissance et le rationalisme de l'époque classique une nouvelle forme de pensée s'instaure, sous l'effet d'une modification dans les dispositions du savoir, qui progressivement déplace le problème du mal hors des marges de l'inédit et de l'abyssal jusque dans le domaine de la connaissance. Le mal devient cette part d'ombre des hommes qu'ils posent comme axiome à partir duquel ils pensent leur vérité.

Même si le silence est brisé en 1465 lorsque paraît le texte latin de Cicéron, De Finibus Bonorum et Malorum, c'est la date de 1551 qui marque la parution du premier texte écrit en anglais sur le mal. Il s'agit d'une traduction de l'Ecclésiaste, que l'auteur choisit d'intituler : The Knoledge Of good and iuyle, other wyse calyd Ecclesiastes, ryght excelente and worthy, of all men to be had in mynde nowe a newe set fourth in meter, by pore Shakerlaye.

Le titre, tel qu'il est formulé, tente une première interprétation exégétique du texte de l'Ecclésiaste, texte par ailleurs, comme le suggère le Talmud (Shabbat, 30b) : «Les Sages voulaient cacher le livre du Qohéleth parce que ses paroles se contredisent».

En effet, ce texte s'inscrit dans la contradiction. Il se donne comme sagesse et comme modification, voire réfutation, de ce même savoir. Sa réflexion, qui présuppose l'enseignement des prophètes, tel qu'il se trouve codifié dans le Deutéronome, dresse des objections à une tradition tenue pour infaillible et qu'il contrecarre par le scepticisme. Le texte du Qohéleth ne se place pas en deçà de l'expérience que traduit le concept du mal. Il se fait le témoin d'une variété d'expériences quotidiennes du mal par les hommes, dont le regard critique fait voler en éclat la sagesse des pères.

L'émergence de la question sur le mal dans l'Ecclésiaste est fondamentale. En effet, non seulement le texte ne conteste pas l'existence du mal, mais l'admet d'emblée. Il ne sera donc pas question, dans cette réflexion, de reposer la question primordiale de l'origine, dont la réponse pour le Yahviste a été donnée de façon définitive dans la Genèse, à savoir que le péché originel a déclenché chez l'homme le déséquilibre d'où proviennent dorénavant tous ses maux :

Nor there is no Just man

upon the earthe at all

That synneythe not, but hourely he

is redy for to fall. 
$\mathrm{Au}$ contraire, il remet en cause la conviction d'une justice divine de colère et de vengeance qu'il cherche à démentir.

$$
\text { I se the godly man }
$$

depraued wrongfully,

As though that he had spent hys tyme in

touyle, and synfully.

(Chapter XII)

Si problème à résoudre il y a, il porte sur la deuxième grande question théologique, demeurée intacte, de savoir comment concilier l'existence du mal avec celle de Dieu, mais encore comment justifier le fait que Dieu ait admis, voire instigué l'avènement du mal. Et voici que se pose une nouvelle fois dans toute son ampleur la question terrible du «comment».

Reste à savoir pourquoi Shakerley a voulu se livrer à la traduction d'un texte réputé cryptique parmi les exégètes et les traducteurs. Pourquoi choisit-il de s'atteler à la traduction d'un récit décousu, de versets qui autorisent plusieurs traductions et sont alignés sans transitions explicatives, de métaphores difficiles à saisir et impossibles à regrouper sous un seul principe directeur; et pourquoi le faire avec un souci de forme et une exigence de rigueur, notamment dans la scansion et la rime ? Pourquoi ce choix d'un texte dont le désordre des propositions, manifeste à la simple lecture, ne semble en rien correspondre, au premier abord, à une Renaissance qui se modelait, dans sa recherche et son écriture, sur les discours méthodiques et la rhétorique des anciens?

As sone as I had reade all thys noble searche, or word Ecclesiastes : me thought that I coulde not occupye my time better, then to sette it out into metre. But yet I stode in greate doubt of two thynges. The fyrste was, that I thought not my selfe able to do it. Secondarily, I thought, that men would have me in disdayne, \& laye greate folly to my charge, for that the excellente Erle of Surreye had gone the path before me. Yet at the laste I agreed wyth my selfe to do it, how be it not so fynely as many other can, neither so well as the Lyght of Lyghtes (I meane the Erle of Surrey).

Faut-il y voir un simple défi intellectuel, Shakerley mesurant ses prouesses de traducteur à celui d'un autre personnage qui l'aurait précédé dans cette entreprise ? Ou bien, voyait-il dans ce texte, la plus pertinente des réflexions sur la question du mal, par rapport à son époque, et la possibilité, 
dans l'exercice de la traduction, de proposer une nouvelle approche du problème?

D'entrée de jeu, le traducteur place la question du mal sous le signe paradoxal de la connaissance («knowledge»). Cette notion complexe qui fait référence à une pratique en même temps qu'à une faculté de savoir est à comprendre dans toute son ambivalence: connaissance intellectuelle, par laquelle la pensée appréhende son objet d'étude; et connaissance d'ordre existentielle, qui se fonde sur le vécu et l'expérience. Cette deuxième forme de connaissance qui relie sujet et objet mais aussi sujet et sujet s'inscrit dans une relation qui ôte au sujet son autonomie et l'accapare d'une présence aliénante, à savoir, le mal.

Dans le premier cas, on comprendra que la connaissance du mal, en tant que conceptualisation de ce qui existe déjà de façon substantive et objective impliquera une définition spéculative du mal. En revanche, dans le deuxième cas de figure, connaître le mal, de manière subjective et qualitative cette fois, équivaudra à en faire l'expérience, et pourra éventuellement mener à l'élaboration d'une sagesse pratique.

L'enjeu de cette double lecture est essentiel : l'Ecclésiaste conclut sur l'inutilité des efforts qui tendraient vers la connaissance en général, et vers celle du mal en particulier. Ainsi, il avoue son échec à comprendre comment le mal vient aux hommes. Certes, il a pu constater que la voie du mal est double et réciproque, puisque pour être commise elle doit aussi être subie. L'Ecclésiaste constate l'existence des justes persécutés aussi bien que des malfaiteurs nullement tourmentés, la conscience intacte. Mais la définition des divers sens ou trajectoires du mal demeure un constat qui n'amorce en rien son explication, de sorte que le mal reste aussi insondable et insoluble aux yeux du Qohéleth, et toute tentative de connaissance se réduit finalement aux errements d'une raison dévoyée.

\section{Livre X}

All these thyngs haue I proued

although my serche were uayne

And daily sought for wisedom but

I coulde her not attayne.

$$
\text { I dyd apply my mynde }
$$

to knowledge in this serche

And for to seke oute sciencis,

whoes pyth I coulde not reach.

And all the paynes I toke

was for no more but this

But that I would in doteyng force

se what greate follye is. 
And lo, I serch full syghte

In wysedomes powre, but sur it neuer

laye wyth in my myghte.

Livre XII

And then I sawe it playne

that vayne it was for me,

To take in hande that noble search

that ended myght not be.

There is no lyueyng man

hat maye the same attayne,

Even though he spent hys lyfe therin

Yet shoulde hys searche be uayne

Wherefore, to hym that sekes

to knowe the treuth of thys

Let hym but trye as I haue done

and therof shall he mysse.

Le réalisme pessimiste qui résulte du seul constat qu'il y aurait une réalité du mal invite le narrateur à une sagesse quelque peu désabusée qui ne pouvait toutefois pas satisfaire les esprits humanistes du seizième siècle. Si le texte biblique dit, en définitive, l'inutilité des efforts qui tendraient vers une connaissance, une sagesse, un savoir-faire ou une politique, le traducteur, quant à lui, formule, dans le titre qu'il donne à l'Ecclésiaste, ainsi que dans son épître au lecteur, un avis contraire :

Yet for that I began thys boke welmoste thre yeres agoe : me thought I myght be so bolde a longe an hundred tayleyng rymes, to put furth thys notable search, the which gentle reader, if thout note well, thou shalte finde wonderfull sentencis, spoken of. Ecclesiastes... that serchith wonderfully to know thinges, whose fame do I delyte to lyghte, with the ende that suche yong men as I, may have the path poynted unto us, by a godlye mynde, and eschewe the euyil \& retayne the good.

Nowe therfore, because I se us all desyrouse of newe thynges, I thought to gyue some newe nan unto this boke and that thou myghtyst the more desyr to se and reade it, I cal it the knowledg of good and ill, whyche is for it a mete name. For from the highest unto the loweste, if thou marke it well, are lessones mete fortobe learned of all men, at all times and in all places. 
A présent, il n'est plus dit que le savoir pourrait accroître la souffrance mais que la science n'augmentera point la douleur. L'intitulé, The knoledge of good and iuyle, pose le mal comme l'altérité invétérée, «le contraire du bien». C'est ainsi que Platon désigne le mal dans le Théetète (176a). Il présente le mal comme une contradiction à comprendre, voire, à terme, à résoudre ou tout au moins à contenir par un art de vivre, qui serait l'un des objectifs proposés par le mot «knoledge». Le titre renvoie, de par sa formulation, aux écrits des auteurs anciens sur «les biens et les maux» (et l'on se souviendra, ici, du titre de Cicéron), à la nuance près que l'éprouvante pluralité des maux se résorbe en un singulier constant et absolu englobant toutes ces catégories plurielles.

Il rappelle, par ailleurs, la primauté du bien sur le mal. Cette primauté apparaît comme une nécessité intellectuelle et morale, qui fonde le principe de sagesse recherché. Le titre de Shakerley semble supposer que le mal ne serait pas perçu comme tel si l'homme n'avait d'abord en lui l'idée, même intuitive, du bien, qui refait surface dès que l'homme est confronté avec le mal. Ainsi, malgré le pessimisme et le scepticisme caractéristiques de l'Ecclésiaste, le traducteur choisit de ne pas abolir le primat du bien tel qu'il apparaît dans la philosophie gréco-romaine.

Remarquons, en outre, que la dichotomie qui oppose le bien au mal présente le problème du mal en termes de valeurs conflictuelles et même contradictoires. De nouveau, cette situation de dualité irréductible apparaît comme une donnée première. Ce faisant, le traducteur ne trahit pas l'esprit de contradiction du texte biblique. Il rend compte, également, d'une pensée archaïque propre aux mythologies originelles, qui explique le monde par un antagonisme manichéen et une disposition à faire s'affronter le camp des bons et celui des méchants.

Lorsque, dans la dernière décennie du seizième siècle, reprend la publication d'ouvrages traitant de la question du mal, on observe cette même structure binaire dans les titres. Cela montre que les auteurs s'attaquent, une fois de plus, au mal, en termes de conflit :

1591 : Perswation to doe Good cheerfully, and to beare Euil patiently.

1594 : Of the Good and Evil Tonge, with the Vnstablenesse of the same. Also the Abuses thereof.

et, bien sûr, 1597 : Of the Colours of Good and Euil, de Francis Bacon, qui pose ainsi la problématique de «comment le mal vient aux hommes» en termes de conflit, mais aussi de dynamique et de mouvement. A présent, la question serait de savoir si le mal vient par une impulsion, une incitation extérieure à l'homme qui le pousse à mal agir, ou naît-il d'une initiative constitutive de l'homme, qui se manifeste par les humeurs ou le désir? Il traite le problème sous l'angle décalé de la vertu, dans la troisième démonstration, intitulée Quod ad veritatem refertur majus est quam quod ad opinionem. Modus autem et probatio ejus quod ad opinionem pertinet haec 
est, quod quis si clam putaret fore, facturus non esset :

Allow that virtue (such as is joined with labour and conflict) would not be chosen but for fame and opinion, yet it followeth not that the chief motive of the election should not be real and for itself ; for fame may be only causa impulsiva, and not causa constituens or efficiens. As if there were two horses, and the one would do better without the spur than the other: but again, the other with the spur would far exceed the doing of the former, giving him the spur also ; yet the latter will be judged to be the better horse. And the form as to say, 'Tush, the life of this horse is but in the spur, and that it is no manner of impediment nor burden, the horse is not to be accounted the less of which will not do well without the spur, but rather the other is to be reckoned a delicacy than a virtue: so glory and honour are spurs to virtue; and although virtue would languish without them, yet since they be always at hand to attend virtue, virtue is not to be said to be less chosen for itself because it needeth the spur of fame and reputation.

La question du mal est abordée dans cette métaphore des chevaux, comme dans la binarité des titres, sur le mode de l'affrontement et de la dynamique de résistance. Dans cette interprétation des sens, le mal s'explique comme une force constante mue par un principe d'impulsion, qui règle, d'un coup, la question du pourquoi et du comment du mal, et fait fusionner la question de l'origine du mal et de son acheminement vers l'homme, tout en la démystifiant, ou du moins en restituant la part d'ombre et de mystère de l'homme en son for intérieur.

Bacon tend vers quelque chose qu'il pressent mais ne saisit pas encore. Tout comme l'Ecclésiaste, qui s'avouait incapable de saisir ce qu'il savait pourtant être au cœur même de sa pensée. Ce donné fuyant est mis en évidence dans le discours du Qohéleth par le principe du démenti et de la mise en doute. En effet le doute constitue alors le mot d'ordre de sa réflexion. Il offre une exigence d'objectivité, mais aussi un relativisme et un réalisme. C'est à partir du doute que l'Ecclésiaste fonde le discrédit jeté sur les préjugés d'une sagesse érigée en tradition. C'est peut-être aussi cette remise en cause que Shakerley cherchait à mettre en évidence dès 1551 lorsqu'il choisit de traduire ce texte énigmatique. 
Après l'époque de l'Armada, un nouveau silence autour de la polémique du mal s'instaure dans les traités et ne sera brisé, une fois pour toutes, qu'un demi-siècle plus tard, en 1645, lorsque paraîtra, au moment de la guerre civile anglaise le traité de Méric Casaubon sur les origines du mal, intitulé : The Originall Cause of Temporall Evils. C'est ainsi qu'on se remettra à débattre, une fois de plus, de l'origine du mal, à une époque de révolution qui prétendra extirper le mal et servir la cause juste en faisant exécuter le roi Charles ${ }^{\mathrm{I}}$, avec l'argument illusoire d'arriver ainsi à rétablir la justice et empêcher dorénavant tout abus de pouvoir

Catherine LIS AK Université d'Amiens 